\title{
O CORO EM O DÍSCOLO DE MENANDRO
}

\author{
Maria Celeste Consolin Dezotti*
}

RESUMO: There is a consensus among scholars that the chorus in Menander's time had become totally detached from stage-action; its performances, marked in the Greek text by the word XOPOY, separated like interludes the acts from each other within the plays; the chorus had a technical function: provide a break in the action to cover certain off-stage events and indicate the passing of time. This paper, however, examines in Dyskolos, one of Menander's early comedies, the relation between the chorus and Cnemon present in the old man's words that makes generalizations about human relationships, and shows that in this comedy the chorus of the followers of the god Pan was exploited by the poet as a source of achieving various dramatic effects.

PALAVRAS-CHAVE: Menandro, O Díscolo, Comédia nova, Coro, Performance.

Dada a impossibilidade de se chegar a resultados definitivos a respeito da dramaturgia grega do séc. IV a.C. - período a que pertence $O$ Díscolo de Menandro —, devido à escassez de documentos e ao caráter fragmentário dos textos, um estudo que pretende analisar o coro cômico dessa comédia deve iniciar-se, a título de prévio consolo, com a observação de Hunter, mencionada por Rothwell (1995, p. 117-118): "Em diversas questões concernentes ao coro nós devemos nos contentar com uma honesta confissão de ignorância."

De fato, são muitas as questões em aberto: o coro cômico continuaria a ser composto de vinte e quatro coreutas, como era no séc.V a.C.? Ou eles seriam sete ou oito, conforme documenta uma inscrição da ilha de Delfos, do séc. III d.C.? (cf. Sifakis, 1967, p. 72). A performance do coro se comporia de canto e dança, ou só de dança? (cf. Ireland, 1995, p. 17 e p. 129). E que dança o coro dançaria? Seria o ballismós, uma espécie de galope? (cf. Lape, 2006, p. 94). Também não se tem resposta para uma questão importante: não se sabe se o coro permanecia na orchestra após a sua primeira entrada ou se ele a deixava e tornava a entrar a cada performance, no intervalo dos atos (cf. Hunter, 1975, p. 10).

Para este estudo, importa considerar que, no tocante à presença do coro nas comédias, não há solução de continuidade entre a comédia política de Aristófanes e a comédia de caracteres de Menandro, pois, enquanto vigorou a coregia ${ }^{1}$, a presença do coro na cena esteve garantida, pois, como bem observa Hunter (1975, p. 9-10), a "a performance do coro era parte do ritual religioso em honra de Dioniso e dificilmente poderia ser eliminada de todo". Contudo, ao longo do tempo ele foi perdendo funções,

\footnotetext{
Professora de Língua e Literatura Gregas do Departamento de Lingüística, Faculdade de Ciências e Letras, UNESP, Câmpus de Araraquara.

Essa instituição existiu, em seu primeiro formato, até o final do século IV a.C., tendo sido, no governo de Demétrio de Falero (317-307), substituída pela agonothesia, que propunha a cooperação de recursos públicos e privados para financiar o coro, eliminando-se, por conseguinte, a competição entre coregos (Lape, 2006, p.91).
} 
mas, como observa Rothwell (1995, p.100), essa diminuição de seu papel não se deu de forma abrupta.

Em Aristófanes, o coro é personagem coletiva que se expressa através de cantos e danças nos estásimos e nos episódios, e participa dos diálogos com falas proferidas pelo corifeu. Por ser personagem com direito a fala, o coro aparece registrado na "lista das personagens". Sua performance lhe permite colaborar tanto no desenvolvimento do enredo como na organização do espetáculo (cf. Oliveira, 2009). Mas algumas inovações importantes para o desenrolar da história do coro cômico já se encontram nas duas últimas comédias supérstites de Aristófanes, Assembléia de mulheres e Pluto.

Em Assembléia de mulheres, que data provavelmente de 392 a.C., o coro de amigas de Praxágora entoa cantos corais, com letra e música compostas pelo poeta, até que o poder político esteja nas mãos das mulheres. A partir daí, os manuscritos não mais registram textos cantados pelo coro. Nos espaços previstos para a intervenção coral encontra-se

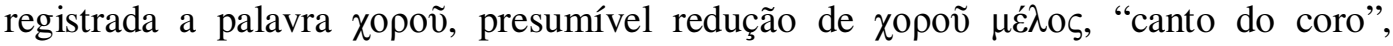
conforme propõe Handley (1992, p. 173), para quem essa prática (e, acrescento, a incerteza sobre o que de fato acontecia em cena neste momento) "deixa o leitor livre para imaginar e o diretor livre para trabalhar com um amplo leque de interlúdios possíveis."

Não se sabe a performance do coro compunha-se de canto e dança. A anotação

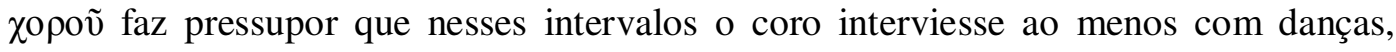
executadas ao som da flauta' (cf. Zagagi, 1994, p. 75). Se havia texto cantado, ele não mais era da autoria do poeta e não mantinha vínculo com a ação dramática, diz Sousa e Silva (1988, p.11; 2007, p. 31). Rothwell (1995, p.111) supõe que o coro cantava canções não motivadas pela ação. Se assim for, esses cantos se alinhariam à tradição do embólimon, interlúdio coral inaugurado na tragédia por Agatão (dramaturgo que obteve a primeira vitória nos concursos em 416 a.C.). Ele lembra, também, que papiros do séc. III a.C. costumeiramente excluíam dos textos das tragédias os cantos corais, e cita como exemplo dessa prática o papiro que contém As Bacantes de Eurípides; portanto, diz ele, "a ausência, nos papiros, dos cantos corais nada prova sobre a autoria deles", ou seja, não se descarta a possibilidade de Aristófanes ter composto esses cantos e eles terem sido eliminados posteriormente.

Outro detalhe de Assembléia de mulheres que merece destaque é que o coro começa a adentrar a orquestra já no prólogo, na altura do v. 30, "em parcelas", como anota Sousa e Silva (1988, p. 115), e vai se agrupando como coro ao entoar o párodo (vv. 285-310). Soma-se a tais singularidades o êxodo do coro após a execução do párodo (para dirigir-se à Pnix, ao encontro das demais mulheres). Uma vez ausente da cena, ele só retorna a ela para cantar o primeiro estásimo (v. 479-504), ficando, portanto, vazia a orquestra durante o desenrolar do primeiro episódio inteiro. Uma vez de volta, o coro permanece em cena até o final da comédia, atuando coreograficamente

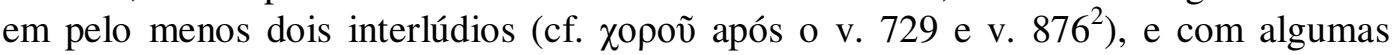
intervenções nos episódios (duas no segundo episódio e quatro no epílogo). Para Oliveira (2009, p.181), a ausência do coro na maior parte da peça é compensada pela atuação, nos episódios, das mulheres revolucionárias, companheiras do coro desde o princípio da peça.

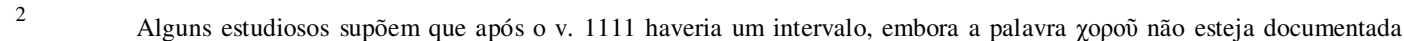
nesse passo em nenhum manuscrito. Esses estudiosos a reconstituem, apoiando-se em necessidades performáticas (distribuição de papéis entre os três atores), cf. Oliveira (2009, p.180); Sousa e Silva discorda dessa reconstituição (cf. 1988, p.107).

Organon, Porto Alegre, nº 49, julho-dezembro, 2010, p.95 -109 
Em Pluto, comédia de 388 a.C., também encontram-se aspectos singulares no tocante ao coro. O coro de camponeses contracena, na primeira parte do párodo, com o escravo Carião (v.253-320), mas nessa performance o canto coral é substituído pela recitação de uma seqüência de zombarias. Na segunda parte do párodo, o coro é instado por Carião a abandonar as zombarias e passar "para uma outra forma" (v. 317, غ̇ $\pi$ ' á $\lambda \lambda$ '

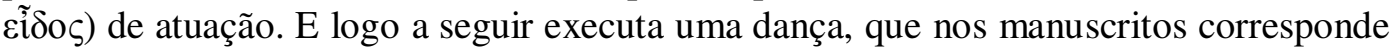

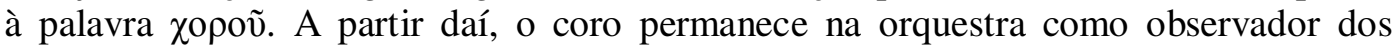
episódios, nos quais intervém através das falas ${ }^{3}$ do corifeu, o chefe do coro, e como executor de danças nos interlúdios, em momentos sempre marcados nos manuscritos

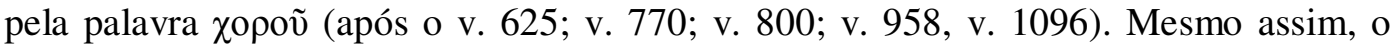
texto documenta que as personagens reconhecem a presença do coro na orquestra; geralmente a primeira personagem que entra em cena após o interlúdio dirige-se primeiro ao coro, havendo uma única vez em que essa interação com o coro é praticada também pela última personagem que deixa a cena (cf. Carião, v.770).

Essas duas comédias de Aristófanes situam-se no início do séc. IV a.C. e são consideradas comédias de transição para o novo formato de comédia conhecido como néa. O Díscolo de Menandro foi representado nas Leneias de 317-316 a.C. - portanto, 72 anos depois de Pluto de Aristófanes, e constitui o único exemplo que podemos conhecer, em texto pouco fragmentado, dessa nova comédia grega.

\section{O DÍSCOLO}

O Díscolo apresenta um coro que não é responsável por nenhuma fala e, por isso, não consta da lista de personagens ${ }^{4}$. Os manuscritos prevêem quatro intervenções

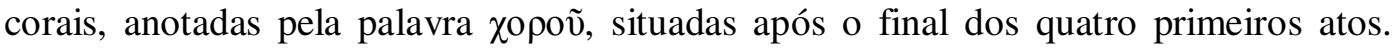
Excetuando-se a introdução do coro na orquestra, feita pelo escravo Daos - o último a deixar a cena no final do ato I - não há em nenhuma fala das personagens qualquer referência textual direta à presença do coro em cena, confirmando-se portanto a ausência de comunicação entre o coro e os atores.

Há indícios, entretanto, de que esse formato coral de $O$ Díscolo convivia com o padrão anterior, em que o coro interagia com os atores, tal qual documentam as comédias de Aristófanes comentadas acima. ${ }^{5}$ A coexistência desses diferentes padrões, aos quais se deve acrescentar o padrão mais antigo, de um coro realmente atuante na trama, e mantido vivo nesse século pelas reencenações de peças do século anterior (cf. Handley, 1992, p.5), formava sem dúvida um variado conjunto de possibilidades para o coro cômico da época de Menandro.

Nosso propósito, neste trabalho, é examinar as possíveis funções do coro de $O$ Díscolo e mostrar que esse coro não era tão completamente desvinculado da ação como tem sido aceito consensualmente pelos estudiosos. Martin (1972, p. 80) afirma que esses interlúdios corais constituíam elementos postiços; Hunter (1975, p. 9) entende que $\underline{\mathrm{a}}$ performance desse coro nada tinha a ver com a peça encenada no palco. Handley (1992, p. 173) segue na mesma toada e afirma que a performance do coro não resulta em

\footnotetext{
3 Cf. no primeiro episódio, vv. 328 e 486; no segundo episódio, vv. 631, 636 e 639; no quinto episódio, v. 961; no epílogo, v. 1207.

Também não constam dessa lista os nomes de outras personagens sem fala, concebidos como meros figurantes, tais como a mãe de Górgias (Mirrina), os servos Dônax e Siro, e as servas Plangon e Partenis.

Segundo Rothwell (1995, p.112), há indícios textuais dessa interação, ainda que modesta, em fragmentos cômicos de Alexis e de Antífanes, dramaturgos do séc. IV a.C. Hunter (1975, p. 36) lembra que a comédia $O$ cabo, de Plauto, ainda apresenta resquício de coro (coro de pescadores).
} 
consequiências para a ação. E há as afirmações contundentes, como a de Ireland (1995, p. 18), para quem "o coro, por ter sido totalmente desligado da ação do palco, tinha dificilmente mais relevância que os intervalos comerciais dos atuais programas de televisão". Nessa afirmação ele reconhece ao coro uma função meramente técnica: interromper a ação e indicar a passagem do tempo necessária para a ocorrência de certos acontecimentos extracênicos.

Zagagi (1994, p. 75), ao mesmo tempo em que assinala a desimportância do coro d' $O$ Díscolo, dizendo que a peça "poderia transcorrer perfeitamente sem a contribuição do coro, qualquer que seja ela", observa que Menandro, nessa comédia, teve a preocupação de conferir ao coro uma identidade — "devotos de Pã"-, que o vincula diretamente à divindade que profere o prólogo e que promove a intriga (p. 72). E vai além: não lhe passa despercebido que a entrada do coro é explorada por Menandro "como uma fonte de realização de vários efeitos dramáticos"; por exemplo, o coro entra em cena logo após o monólogo em que Daos critica a negligência de Cnêmon para com a filha, fazendo aflorar um forte efeito cômico resultante do contraste entre a profunda indignação moral do escravo e a entrada de um bando despreocupado de devotos embriagados (p. 73).

Esses efeitos, que se realizam durante o espetáculo, foram mais explorados recentemente por Susan Lape (2006), que chegou à conclusão de que Menandro conferiu ao coro de pelo menos quatro de suas comédias, entre elas $O$ Díscolo, o caráter de komos (p. 92). O komos, segundo ela (2006, p. 94-95), é uma instituição cultural de natureza performática; em seu sentido básico, é uma folia, uma celebração coletiva e processional realizada ao som de cantos, muitas vezes regada a vinho, executada em contexto religioso (por exemplo, uma procissão ao santuário de um deus) ou em contexto profano, em celebrações ligadas ao oikos, tais como em simpósios, cortejos amorosos, casamentos ou comemorações de vitórias. Sendo o coro em Menandro um komos, sua formação para a performance não seria em círculo ou em retângulo, mas mais ou menos linear, à maneira de procissão (p. 98).

Embora os manuscritos de Menandro não tenham conservado nenhum canto de komos, Susan Lape acredita que "o espetáculo visual do komos na cena não teria sido tão insignificante para o público" (p. 94), que, familiarizado com essas práticas culturais, teria estabelecido relações entre o coro e as diversas situações dramáticas que justificariam a presença de um komos. No que respeita especificamente à comédia $O$ Díscolo, ela aponta três situações propícias: o sacrifício que a mãe de Sóstrato vem realizar em honra a Pã, no ato III (komos religioso), a celebração do compromisso de casamento no ato IV (komos profano) e, no epílogo, a celebração da vitória dos escravos sobre Cnêmon, digna de epinício (komos profano), que, nos versos finais, se emenda a uma prece pela vitória do poeta no concurso cômico.

Por fim, ela conclui que o coro-komos não tinha apenas a utilidade formal de marcar a divisão de atos, mas contribuía visualmente, no plano poético, para o desenrolar da trama, prenunciando e enfatizando a celebração final comunitária (2006, p. 94 e 98$)$.

\section{O CORO COMO ELEMENTO DO ESPETÁCULO}


Nossa análise ${ }^{6}$ também considera que, mesmo sem texto, o coro é um elemento significante, no plano do espetáculo. E mostraremos que, de certa forma, os significados que ele veicula estão considerados no interior das falas de Cnêmon, cujo caráter rabugento o coro estimula a manifestar-se. Nesse sentido, diremos que há relações semiológicas entre essa personagem e o coro.

O coro de $O$ Díscolo mantém com a trama um indiscutível vínculo temático:

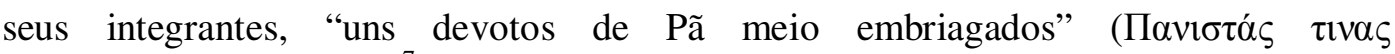

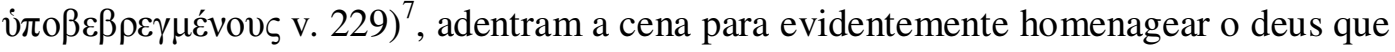
habita o ninfeu vizinho da casa de Cnêmon, o velho díscolo que o título da peça focaliza. A justificativa para a entrada desse coro está no prólogo proferido por Pã: o

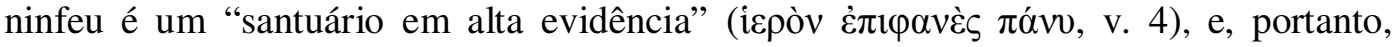
muito freqüientado. Mas o prólogo também adianta que Cnêmon não suporta "multidão"

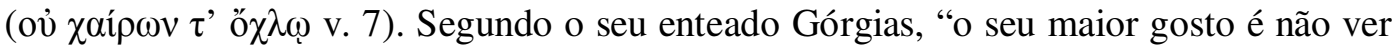
ser humano algum" (v. 332-333). Portanto, a fama do santuário submete Cnêmon a uma freqüentação, a um permanente e inevitável convívio social totalmente incompatível

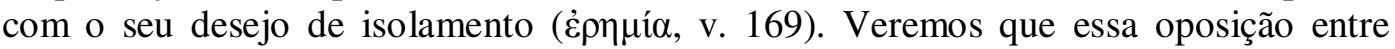
convivência $x$ solidão é estrutural para o desenrolar da trama da comédia.

Em muitos momentos Cnêmon protesta contra essa freqüente circulação de pessoas nas imediações de sua casa. Ao ver aproximar-se a comitiva da mãe de Sóstrato, profere: "O que significa esta desgraça? Uma multidão!" ( ő $\chi \lambda$ os $\tau$ « v. 431-32) $)^{8}$.

De fato esta é "uma multidão" particular, dentre as muitas multidões que povoavam os seus dias, conforme ele mesmo informa ao entrar em cena no ato I (v.153166):

Pois não era mesmo um sortudo aquele Perseu?

E por dois motivos: porque se tornou alado

e não deparava com nenhum ser que anda no chão,

e porque possuía o tal pertence com que em pedras

transformava todos os importunadores. Pudesse eu ter agora

um igualzinho! Nada mais abundante haveria

do que estátuas de pedra por toda parte!

Mas o fato é que a vida está insuportável, por Asclépio!

Eles já vão tagarelando e embarafustando

no sítio. É que meu hábito é ficar de prosa

bem na beira do caminho, por Zeus! Justo eu que não lavro

essa parte do sítio, só para ficar fora do alcance

dos passantes. Mas eles já vão xereteando colina

acima! Que fartura de multidão!

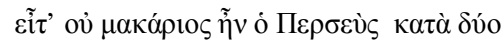

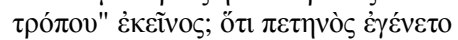

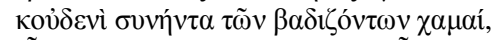

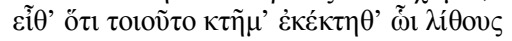

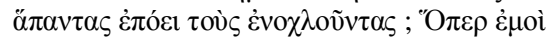

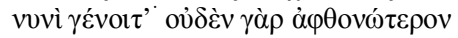

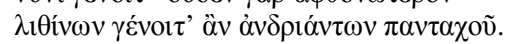

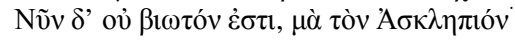

6 Esse estudo deve muito à representação da comédia $O$ díscolo realizada pelo Grupo Giz-en-scène de Leituras Dramatizadas de Textos Clássicos em maio de 2009, na XXIV Semana de Estudos Clássicos da Faculdade de Ciências e Letras da Unesp, câmpus de Araraquara. O espetáculo revelou-me sentidos até então ocultos no texto.

As traduções de $O$ Díscolo citadas neste trabalho são de minha autoria, conforme texto grego editado por J.-M. Jacques

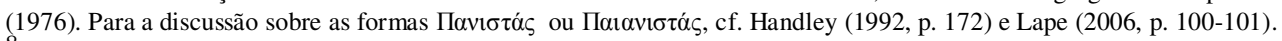

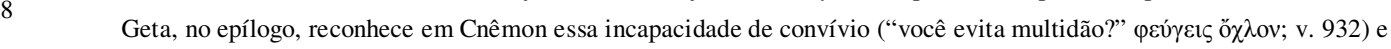
quer puni-lo por esse defeito. 


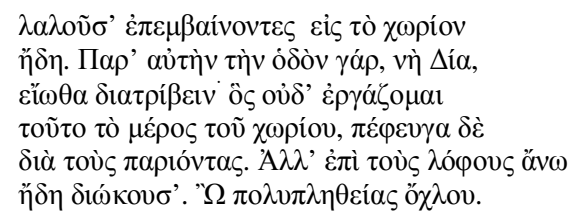

Interessa notar, nessa fala de Cnêmon, o seu sentido generalizante; embora adentre a cena logo após ter escorraçado o escravo Pírrias (que, incumbido de uma missão em benefício de Sóstrato, havia entrado no seu sítio), Cnêmon não faz menção alguma a esse visitante indesejado. Seu comentário tematiza a situação geral e rotineira que o vem torturando há tempos, vítima do permanente tumulto de pessoas que, a seu ver, são atraídas pelo santuário. Seus comentários, portanto, desconsideram o singular e

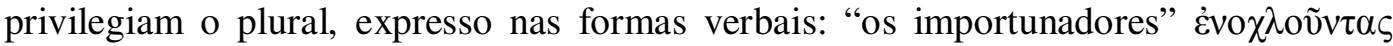

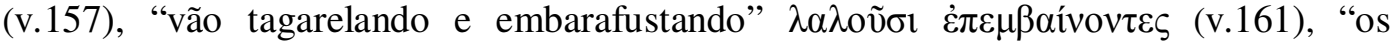

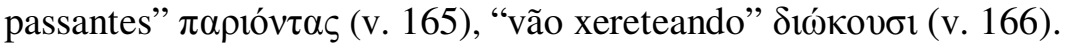

Ireland (1995, p. 125) entende o uso dessas formas plurais como prova de um defeito de Cnêmon: a tendência ao exagero. Ao contrário de Ireland, entendemos que não há exagero nas falas de Cnêmon; o que ele faz é assinalar que uma determinada situação particular e presente (por exemplo, as presenças indesejadas de Pírrias e de Sóstrato) se apresenta, a seus olhos, como idêntica a outras situações já vivenciadas. E para deixar indicado que tal situação deve ser vista como parte desse conjunto maior, ele usa do recurso da generalização.

Esse caráter generalizante de seus protestos é um traço constante de suas falas. Ele está presente na fala que Cnêmon profere no primeiro encontro com Sóstrato. Nesse momento, Sóstrato se encontra sozinho em cena, postado diante da casa do velho, mas este se expressa como se estivesse se dirigindo a um grupo de interlocutores (v.173177):

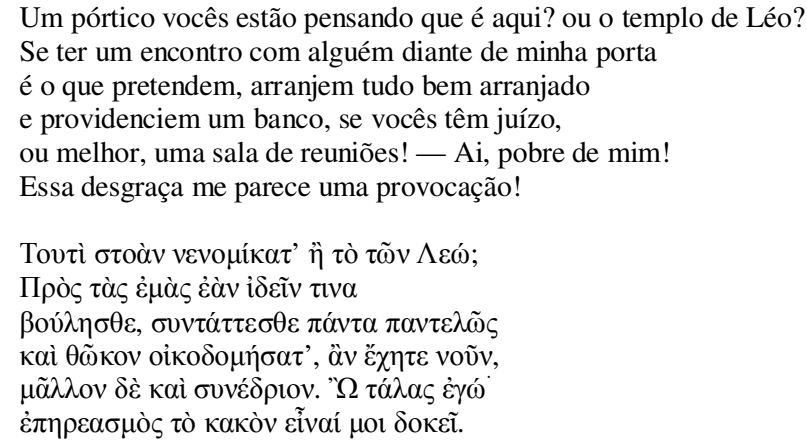

O mesmo procedimento marca a reação de Cnêmon ao enxotar Geta, quando este vem sozinho lhe pedir emprestada uma caçarola (v.481-482):

Essas feras assassinas! vão logo batendo à porta

como se fosse a casa de um amigo.

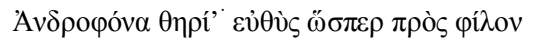

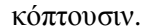


O interessante é que, logo a seguir, Cnêmon refere-se a Geta particularizando-o, com a expressão "o de agora" (ó võv, v. 485), isto é, "o sujeito que bateu à minha porta agora há pouco".

Coerentemente com sua reação misantropa, que o leva a ver todos os que o procuram como parte de um mesmo grupo de pessoas indesejáveis, ele age da mesma maneira com o cozinheiro Sicon (v. 506): "Não tenho marmita, nem machado, nem sal, nem vinagre, nem nenhuma outra coisa". Sua resposta já antecipa a negativa para qualquer tipo de solicitação que ele imagina que Sicon pudesse emendar à primeira. Nessa resposta, Cnêmon registra a variedade de solicitações que ele costumava ouvir de tantos devotos que, ao notarem que haviam esquecido algum petrecho necessário para o banquete sacrificial, não hesitavam em bater à sua porta.

Ao sair de casa para voltar ao campo, depara com a mãe de Sóstrato e sua comitiva e, vendo-se forçado a voltar para casa, exclama (vv.442-44):

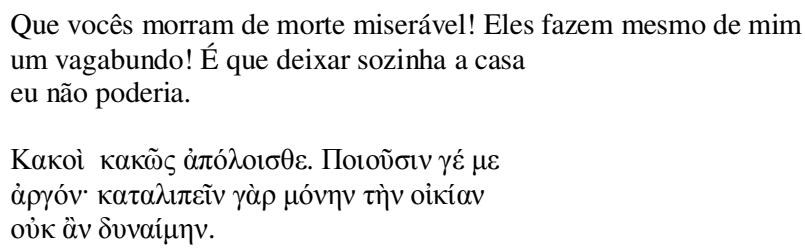

Nessa fala, ele se dirige primeiro à comitiva: "que vocês morram de morte

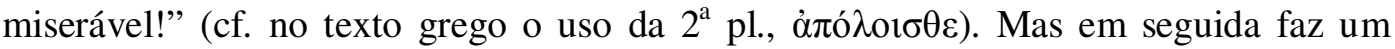

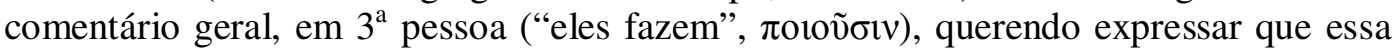
não é a única vez que teve alterada a sua rotina diária. A mãe de Sóstrato, portanto, é apenas mais um ser humano que perturba o seu sossego.

Mas o sossego de Cnêmon não é perturbado apenas pela mera afluência de pessoas ao santuário. Não se pode desconsiderar um dado agravante: o culto ao deus Pã é barulhento, musical. A mãe de Sóstrato, ao aproximar-se do santuário, recomenda à flautista (v.432-434):

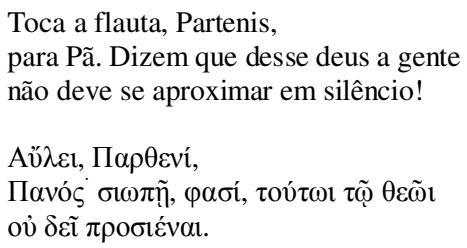

Além do culto ruidoso, o deus Pã, nessa comédia, também é homenageado com uma festa noturna ( $\pi \alpha v v 0 \chi i ́ \varsigma$ v. 856), ocasião em que é celebrado o compromisso de casamento de Sóstrato com a filha de Cnêmon. Enquanto essa festa noturna transcorre no interior da gruta, o escravo Geta e o cozinheiro Sicon aproveitam para castigar Cnêmon à revelia dos parentes dele, que estão na festa. Segundo Geta, o momento é propício justamente porque a festa é muito ruidosa. Diz ele (v. 901-02): "há algazarra lá

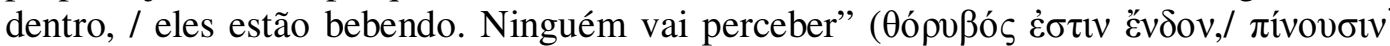

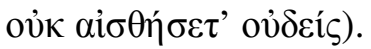

Esse jogo entre o geral e o particular, portanto, estrutura o modo como Cnêmon reage à presença de Sóstrato e da comitiva da mãe desse jovem, tomando-os como casos particulares que remetem a um conjunto geral de presenças perturbadoras de sua solidão. Tal jogo se confirma como expediente de construção de sentidos do texto 
quando o vemos reiterado em um comentário do cozinheiro Sicon, que, ao saber que o velho havia caído no poço, recomenda às mulheres da gruta que façam libações pela sua salvação, ao preço de ele ficar estropiado e coxo,

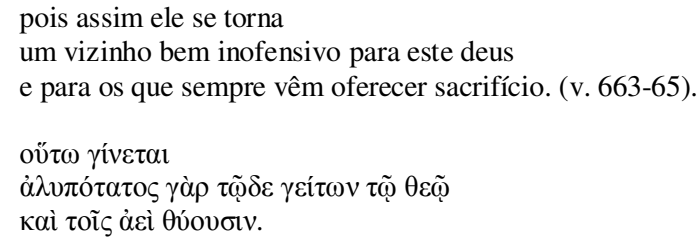

Ora, a fala de Sicon generaliza a situação particular da mãe de Sóstrato, a qual veio à gruta oferecer sacrifício ao deus, incluindo-a na categoria geral dos "que sempre vêm oferecer sacrifício", reforçando, portanto, que, no tocante aos fiéis, os quadros vistos em cena devem ser interpretados como um exemplo dentre um conjunto numeroso de ocorrências.

Propomos interpretar, à luz dos sentidos que afloram nesse jogo entre o geral e o particular, as intervenções do coro nos interlúdios. Apresentado como "uns devotos de Pã meio embriagados" (v. 229-30), o coro é caracterizado de maneira genérica e deve ser interpretado como um dos constantes grupos de devotos que afluíam àquele

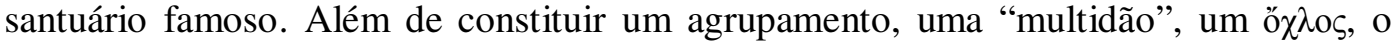
coro realiza sua performance sob efeito de vinho e ao som da música executada pelo flautista em cena (cf. v. 880 e 910; cf. Handley, 1992, p. 209). Ou seja, ele se configura como um komos folião, como o define Lape, mas a meu ver ele atua, desde a primeira intervenção, como um komos religioso, visto que entra em cena textualmente vinculado ao culto de Pã (cf. v. 663).

\section{CNEMMON E O CORO}

Importa, para esta análise, reter que esse coro genérico constitui um pesadelo para Cnêmon, pois ele realiza suas performances barulhentas junto à casa do velho, situada, como bem observa Handley (1992, p.24), "literalmente ao lado do santuário". Portanto, mesmo recluso, Cnêmon podia ouvir a folia dos devotos, assim como podia ouvir a algazarra das festas noturnas que os devotos realizavam no interior da gruta e que, sem dúvida, importunavam o seu repouso. Convencido de que o responsável pelo seu problema é o santuário, Cnêmon responsabiliza as ninfas, suas vizinhas, por seu desassossego e pensa em mudar a casa de lugar (v. 444-47).

Para confirmar a relação entre Cnêmon e o coro, vejamos os significados de cada um dos interlúdios corais.

A primeira performance do coro ocorre após a apresentação feita por Daos, no final do ato I (v. 229-232). Essa folia do coro mantém vínculos com o ato I. O primeiro vínculo a ser apontado é que ela constitui, como todas as demais performances, uma demonstração em cena de um fato rotineiro e, portanto, uma ilustração dos motivos que justificam os protestos proferidos por Cnêmon; desse modo, é legítimo pensar que a presença do coro, somada à presença de Sóstrato no ato I, constitui um bom motivo para Cnêmon não sair de casa no ato II. O segundo vínculo é que esse bando de embriagados passa, aos olhos de Daos, a constituir, juntamente com Sóstrato, uma ameaça para a Mocinha, filha de Cnêmon, a qual se viu obrigada a sair de casa sozinha para buscar água na fonte das ninfas. 
Findo o ato II (v. 426), o coro realiza a segunda performance. Nesse momento Cnêmon ainda está no interior da casa, mas na certa ouve o coro. Terminada a performance do coro, é significativo que seja ele a primeira personagem a entrar em cena na abertura do ato III e faça, ao sair de casa, recomendações à ama para não abrir a porta a ninguém. Ao ver chegar a mãe de Sóstrato e sua comitiva, torna a entrar em casa, lamentando não poder voltar ao trabalho.

A terceira intervenção do coro acontece enquanto Cnêmon, no espaço extracênico, tenta retirar do poço a enxada que a velha ama havia derrubado, mas a corda se rompe e ele despenca dentro do poço. Novamente insistimos em que o velho, mesmo do quintal de sua casa, estaria ouvindo, certamente irritado, a folia do coro.

A quarta intervenção, após o final do ato IV, já será recebida por Cnêmon com outra disposição de ânimo, sem irritação (cf. v. 692). Acontece que, no decorrer do ato IV, o velho é salvo pela generosidade de Górgias, seu enteado. Surpreendido pelo inesperado gesto filantrópico de seu enteado, que, a bem da verdade, tinha todos os motivos para deixar o padrasto abandonado no fundo do poço, Cnêmon reavalia as suas próprias maneiras e resolve conformar-se com a situação, não sem antes tomar medidas que de certo modo possam garantir o seu sossego: ao instituir Górgias como seu herdeiro e tutor da Mocinha, o velho transfere a ele todas as suas obrigações e, portanto, não mais precisará sair de casa ${ }^{9}$. São significativas suas palavras iniciais e finais:

Estou calmo. De hoje em diante Cnêmon não mais atrapalhará vocês (v. 692-94).

$\mathrm{O}$ velho rabugento e difícil não mais será um tropeço para vocês (v. 747).

Merece destaque a forma "vocês", v́ $\mu$ ĩv no texto original. Nesse momento o velho encontra-se todo estropiado, em conseqüência da queda no poço, e está rodeado dos parentes: a esposa, o enteado, a ama e a filha. Mas vale notar que os parentes não são os únicos destinatários da fala de Cnêmon; junto deles encontra-se Sóstrato, que permaneceu por ali confortando a Mocinha, filha de Cnêmon. E o pronome "vocês" refere-se mais propriamente a Sóstrato, que, para Cnêmon, até esse momento, era um estranho, um dos devotos que costumam frequientar o local. Portanto, Sóstrato é novamente tomado nesse momento como um representante do grupo contra quem o velho, até há pouco, se indispunha e que, a partir desse momento, promete não mais hostilizar. Assim, a quarta intervenção do coro confirma que a situação nas imediações da casa de Cnêmon vai permanecer a mesma: os devotos continuarão a festejar ruidosamente o deus, mas Cnêmon não mais se irritará com isso.

Segundo Zagagi (1994, p. 75), os papiros nada informam a respeito dos movimentos do coro. Não se sabe se o coro de devotos permanecia na orquestra após a performance de cada interlúdio, ou se ele fazia várias entradas. Também não se sabe se ele ainda permanecia em cena no final da peça.

A partir das considerações tecidas acima sobre os significados do coro para a expressão do perfil de Cnêmon, imaginamos que a hipótese de o coro sair de cena após cada interlúdio é mais frutífera para a economia do espetáculo. Essa estratégia obriga o coro a fazer várias entradas e possibilita que ele, configurado que é como um coro de devotos, de caráter genérico, possa, a cada nova entrada, ser recebido nesse mundo ficcional como um komos novo, representando em cena a assídua e, para Cnêmon, indesejada afluência de devotos ao santuário. Essa hipótese tem amparo na tradição de

9 É o que deixam claro os vv. 735-36: "Mas, se eu continuar vivo, deixe-me viver como eu quero. / e as minhas tarefas assuma-as você mesmo e execute-as".

Organon, Porto Alegre, $\mathrm{n}^{\circ}$ 49, julho-dezembro, 2010, p.95-109 
Aristófanes, que projetou para a Assembléia de Mulheres um coro que se ausenta da orquestra entre o párodo e o primeiro estásimo.

As análises apresentadas nos levam a concluir que o coro, além da função técnica de preencher os interlúdios, necessários para viabilizar a representação, possibilitando, por exemplo, a troca de máscaras e de figurinos, e para marcar a passagem do tempo em que transcorrem ações extracênicas, apresenta outras funções ligadas à ação dramática que, a nosso ver, não tinham até o momento sido consideradas: a) ele caracteriza o espaço da ficção (espaço dramático) como um lugar movimentado, turbulento, que perturba a rotina sorumbática de Cnêmon e o põe irritado; desse modo, ele espicaça a misantropia do velho ranzinza e contribui para determinar as suas ações em cena;

b) se o coro representa em cena a reiteração do fato geral - a afluência de devotos da mesma forma que a mãe de Sóstrato constitui, no tempo presente da ficção dramática, uma amostra "dos que vêm sempre oferecer sacrifício", então ele interfere na temporalidade da ação representada: ele se reflete enquanto tempo anterior no tempo presente da ficção, restrito ao desenrolar da trama que envolve a família de Sóstrato e a família de Cnêmon, e se instaura como sustentáculo para os comentários generalizantes de Cnêmon.

"Tudo o que pertence ao tempo pode ser figurativizado por elementos espaciais", ensina Ubersfeld (2005, p. 131). O coro d'O Díscolo, sendo significante para a configuração da personagem principal, e ao mesmo tempo para o espaço e o tempo dramáticos, não pode ser considerado um elemento desvinculado da ação.

\section{BIBLIOGRAFIA}

HANDLEY, E.W. The Dyskolos of Menander. London: Bristol, 1992.

HUNTER, R. L. The new comedy of Greece and Rome. Cambridge: Cambridge Univ. Press, 1975.

IRELAND, Stanley. Menander. The bad-tempered man. Warminster: Aris \& Phillips, 1995.

JACQUES, Jean-Marie. Ménandre. Le Dyskolos. Paris: Les Belles Lettres, 1976.

LAPE, Susan. The poetics of the komos-chorus in Menander's comedy. American Journal of Philology, Baltimore, n. 127, pp. 89-109, 2006.

MARTIN, Jean. Ménandre. L'Atrabilaire. Paris : PUF,1972.

OLIVEIRA, Jane Kelly. As funções do coro na comédia de Aristófanes. Tese de doutoramento. Araraquara, SP, 2009.

ROTHWELL, Kenneth S. The continuity of the chorus in fourth-century attic comedy. in: DOBROV, G.W (Org.). Beyond Aristophanes. Transitions and diversity in Greek comedy. Atlanta: Scholars Press, 1995. pp. 99-118.

SIFAKIS, g.m. Studies in the history of Hellenistic Drama. London: The Athlone Press; Univ. of London, 1967.

SOUSA E SILVA, Maria de Fátima. Aristófanes. As mulheres no parlamento. Introdução, tradução e notas. Coimbra: Instituto Nacional de Investigação Científica, 1988.

SOUSA E SILVA, Maria de Fátima. Menandro. $O$ díscolo. Introdução, tradução e notas. Coimbra: Instituto Nacional de Investigação Científica, 1989. 
SOUSA E SILVA, Maria de Fátima. Menandro. Obra completa. Introdução, tradução do grego e notas. Lisboa: Faculdade de Letras da Universidade de Coimbra; Imprensa Nacional - Casa da Moeda, 2007.

UBERSFELD, Anne. Para ler o teatro. Tradução de Lidia Fachin et alii. São Paulo: Perspectiva, 2005.

ZAGAGI, Netta. The comedy of Menander. Convention, Variation \& Originality. London: Duckworth, 1994. 